\title{
Sound pressure levels in the Neonatal Intensive Care Unit
}

\author{
NÍVEL DE PRESSÃO SONORA EM UNIDADE DE TERAPIA INTENSIVA NEONATAL
}

\author{
NIVEL DE PRESIÓN SONORA EN UNIDAD DE TERAPIA INTENSIVA NEONATAL
}

\section{Priscila Vendramini Peixoto ${ }^{1}$, Marco Antônio Nabuco de Araújo², Tereza Yoshiko Kakehashi³, Eliana Moreira Pinheiro ${ }^{4}$}

\section{ABSTRACT}

The objectives of the study were to assess sound pressure level (SPL) in two rooms of a Neonatal Intensive Care Unit (NICU) and to identify their sources. This quantitative-descriptive study was conducted in two rooms of a NICU of a University Hospital in São Paulo, Brazil. Three dosimeters were used to register SPL (total of 261 hours). A 48-hour register of noise sources was obtained. The results showed high SPL in both rooms. The greatest mean Leq were 71.0 $\mathrm{dBA}$ (room A) and 68.0 dBA (room B). Main noise sources in both units were: NICU hallway noise, traffic and conversation among professionals. The results indicate that SPLs in NICU rooms are higher than the levels recommended by regulatory agencies. A guideline was developed and an educational program was implemented as a means to reduce sound pressure levels.

\section{DESCRIPTORS}

Noise

Intensive Care Units, Neonatal

Neonatal nursing

Humanization of assistance

\section{RESUMO}

Os objetivos deste estudo foram verificar o nível de pressão sonora (NPS) de duas salas de Unidade de Terapia Intensiva Neonatal (UTIN) e identificar as suas fontes. É uma pesquisa quantitativa, descritiva, conduzida em duas salas de UTIN de hospital universitário de São Paulo - SP, Brasil. Registros de NPS foram realizados por três dosímetros, totalizando 261 horas de mensuração. Obteve-se 48 horas de registros das fontes que produzem ruídos. Os resultados indicam elevados níveis de pressão sonora nos dois ambientes. Os maiores níveis de Leq foram 71,0 dBA na sala $A$ e $68,0 \mathrm{dBA}$ na sala B. As principais fontes de ruído encontradas nas duas unidades foram ruído no corredor, trânsito e conversa entre os profissionais. Os resultados revelam que os NPS das salas da UTIN estão distantes dos recomendados pelos órgãos regulamentadores. Foi desenvolvido um protocolo e implementado um programa educativo, visando à redução dos níveis de pressão sonora.

\author{
DESCRITORES \\ Ruído \\ Unidades de Terapia Intensiva Neonatal \\ Enfermagem neonatal \\ Humanização da assistência
}

\section{RESUMEN}

Este estudio objetivó verificar el nivel de presión sonora (NPS) de dos salas de Unidad de Terapia Intensiva Neonatal (UTIN) e identificar sus fuentes. Estudio cuantitativo, descriptivo, llevado a cabo en dos salas de UTIN de hospital universitario de San Pablo-SP-Brasil. Se realizaron registros de NPS con tres dosímetros, totalizando 261 horas de medición. Se obtuvieron 48 horas de registros de las fuentes que producen ruidos. Los resultados indican elevados niveles de presión sonora en ambos ambientes. Los mayores Leq medios fueron $71,0 \mathrm{dBA}$ en sala $A$ y $68,0 \mathrm{dBA}$ en sala $B$. Las principales fuentes de ruido encontradas fueron: ruidos en el corredor, tránsito y conversación entre profesionales. Los resultados revelan que los NPS de salas de UTIN distan de ser los recomendados por los órganos reguladores. Se desarrolló protocolo y se implementó programa educativo, apuntando a la reducción de la presión sonora.

\author{
DESCRIPTORES \\ Ruido \\ Unidades de Terapia Intensiva Neonatal \\ Enfermería neonatal \\ Humanización de la atención
}

\footnotetext{
${ }^{1}$ Nursing undergraduate, Escola Paulista de Enfermagem da Universidade Federal de São Paulo. Holder of a FAPESP grant. São Paulo, SP, Brazil. pricalindinha_7@hotmail.com 2²ngineer. Doctor at Instituto Nacional de Metrologia, Normalização e Qualidade Industrial (INMETRO). São Paulo, SP, Brazil. nabuco@inmetro.gov.br ${ }^{3}$ Nurse. Ph.D. in Nursing. Professor at Escola Paulista de Enfermagem da Universidade Federal de São Paulo and Escola de Terapias Orientais de São Paulo, SP, Brazil. terezayk@ig.com.br. ${ }^{4}$ Nurse. Ph.D. in Nursing. Professor of Pediatric Nursing Class at Escola Paulista de Enfermagem da Universidade Federal de São Paulo. São Paulo, SP, Brazil. pinheiro@unifesp.br
} 


\section{INTRODUCTION}

The technical-scientific advancements observed over the last years, together with the implementation of Neonatal Intensive Care Units (NICU) permitted the survival of neonates in critical conditions that were once considered unfeasible. Those evolutions, however, have brought deep changes to the health care environment of newborns (NB), which is today one of the main centers of attention of professionals who care for neonates and their families. One aspect to be considered in the NICU ecology is the noise. Noise is disorganized sounds at frequencies that are physiologically incompatible with the human ear, and may thus cause physical injuries, as well as psychological and behavioral alterations ${ }^{(1-2)}$. In the NICU environment, the different sources of noise reach levels so high that they harm the baby's development and interfere in the work of health professionals and in the behavior of the patients' families.

The harmful effects of noise observed among premature infants are: apnea, cochlea injury, hearing loss, and sleep disturbances. This, in turn, causes agitation and irritability, increased crying and intracranial pressure, which predispose NB to intraventricular hemorrhage. The increased oxygen consumption and heart rate in the NB results in a greater consumption of energy and delayed weight gain, which prolongs hospital stay ${ }^{(3)}$.

The prolonged exposure of health professionals to noise levels above $80 \mathrm{dBA}$ during shifts of 10 to 12 hours, can cause hearing loss, arterial hypertension, vasoconstriction, increased catecholamine release, as well as of the adrenocorticotropic hormone, cortisol, peristalsis and muscular tension, high cholesterol, changes to the immunological system, and sleep disorders ${ }^{(4)}$. There are reports that noise can trigger fatigue, irritability and distraction, which interferes on the worker's performance leading to errors in their activities, and the consequent threat to the neonates' safety ${ }^{(5-6)}$. A NICU study demonstrated that the noise present in that environment affects the professionals' motivation to interact with the patient's family ${ }^{(7)}$.

As to the parents of hospitalized neonates, some studies have given evidence that the NICU increases their stress levels, as it is a place with restricted accessibility, where invasive procedures are performed and the NB is connected to cables and several devices. At the same time, several studies have found that the noise produced by the devices make it more difficult for the neonates to hear and identify their parents' voice, therefore reducing responsiveness in the interaction process ${ }^{(8)}$. These two factors may make it difficult for parents to be present with their hospitalized child and thus interfere in the development of attachment ${ }^{(9)}$.
The main sources of noise at the NICU referred in national and international literature were: the conversations between workers and/or families, the alarm sounds from the devices, high water flow on taps, cutting paper towels to dry hands, using a floor polisher, closing the door and trash lid carelessly, among others ${ }^{(3,10-11)}$. Sound pressure levels above 50 dBA were also found at the NICU when medical/nursing teams changed shifts, and during medical visits $^{(12)}$

Based on the assumption that the NICU of a university hospital can have sound pressure levels (SPL) above values recommended by regulatory agencies, and that the implementation of an educational program on the reduction of noise can help the promotion of an environment that is acoustically more appropriate, the purpose of this study is to know the real acoustic conditions of the NICU in order to obtain subsidiary information to elaborate an educational program. It is expected that this program can make workers incorporate environmental health as an essential component of safe neonatal care and promote the occupational health of those working at the NICU.

The study objectives were: to evaluate the sound pressure levels and identify the sources of noise in a Neonatal Intensive Care Unit of a University Hospital in São Paulo-SP, Brazil.

\section{METHOD}

This quantitative, descriptive study was performed at two NICU rooms of a University Hospital in São Paulo- SP, Brazil.

Each environment (room $\mathrm{A}$ and room $\mathrm{B}$ ) of the NICU has four beds. The area is of approximately $23.80 \mathrm{~m}^{2}$, the ceiling height is $3.40 \mathrm{~m}$, the room is floored with vinyl material, the walls are made of masonry, concrete ceiling and glass windows with screens that remain continuously open, exposing the environment to the noise from the streets. The rooms are located opposite the nursing station, where the telephone and cabinet with controlled drugs are located, and some workers are stationed. Next to the nursing station there is a hallway where all health professionals, students and doctors transit and meet for clinical discussions and to make prescriptions.

It should be stressed that, in general, the medical and nursing teams change shifts next to the incubator, which is also where nursing prescriptions are informed. In addition to the presence of the NICU teams, the unit also has physiotherapists, psychologists and social workers.

Parents can stay in the NICU room with their children from 9am to 9pm, where they frequently receive information about the baby's clinical evolution. The visits of 
grandparents, siblings and other relatives are performed on weekends and holidays.

The floors of the two rooms are cleaned Monday and Tuesday nights. The hallway floor is cleaned on Monday and Wednesday nights, and the nursing station is cleaned on Friday nights. An industrial floor polisher is used in the process. Neither room had air conditioning.

Data collection was performed using three Quest 400 dosimeters from January 12 to 25,2009 . The devices are able to record SPL by the minute, and were set as follows: response time (slow), sound pressure level measured in decibels $(d B)$ and using $A d B(A)$ frequency weighting ${ }^{(13)}$. The $A(d B A)$ scale is the filtering method that mimics the receptive characteristics of the human ear, and is indicated for capturing continuous sounds at an equivalent sound pressure level $(\mathrm{Leq})^{(14)}$. The device was programmed to operate in SPL intervals between 40 and $140 \mathrm{~dB}(\mathrm{~A})$. Therefore, the duration of each captured sound level was precisely recorded and stored, giving researchers a group of data for statistical treatment and analysis.

The dosimeters were hung from the center of the quadrant of each room, at different heights $11.65 \mathrm{~m}$, $1.70 \mathrm{~m}$, and $1.90 \mathrm{~m}$ ) and at least $1 \mathrm{~m}$ away from the walls and floor, complying with Brazilian recommendations ${ }^{(15)}$. The devices were positioned at different heights so that the three microphones would not be on a level parallel to any of the room surfaces, with the purpose to reduce any influence from standing sound waves. The batteries of the devices were changed on a daily basis, and the Leq recordings and calibration of the dosimeter (with the QC10 calibrator) were performed at the end of each shift.

In the data collection strategy it was expected that the device would remain on for 24 hours for two consecutive weeks, adding up to a total of 336 hours, with one device in each room. Of that total, the sample resulted in 261 hours of SPL recordings, because 33 recording hours were lost due to a technical problem with the dosimeter measurements. In addition, before proceeding to data analysis, the recordings of the first and last 30 minutes of the shift were disregarded, considering that the three dosimeters were not turned back on at the same time and here was a possibility of making noise while handling the devices to calibrate and reinstall them, which could affect the Leq in that period. Hence, a total 42 recording hours were disregarded.

The noise source recordings were made by structured non-participant observation. A total 48 recording hours were obtained, i.e. 24 hours in each room, covering all days of the weeks and work shifts. A noise source inventory was created for data collection, based on the condition of the service and the data documented in the literature ${ }^{(11,16)}$.

Considering the possibility that the behavior of NICU workers could be affected on the account of the presence of the researchers and devices, a two-week desensitization period was implemented. During that period, the dosimeters remained positioned on the ceiling and the researchers observed all the procedures that would be performed during the definitive data collection period. This way, they simulated the battery exchanges, Leq recordings and recalibrations at the end of each shift. Also during that period, the researchers performed a pre-test of the inventory and trained the observers. The training was considered to be satisfactory when an $85 \%$ agreement rate was reached in the researchers' recordings (17).

All the recordings made by the dosimeters were transferred to the QuestSuite software, which permitted to perform data treatment using Microsoft Excel. The continuous and equivalent SPL (Leq) were obtained for the data recorded by each dosimeter on the different shifts and days in both rooms. From these data we obtained the spatial means between the three results, as well as the standard deviation between them on different days and shifts in rooms A and B. Before initiating the data collection, the study was approved by the Research Ethics Committee at the University and received authorization from the hospital director (document number 0391/07).

\section{RESULTS}

The results of all measurements in room $A$ indicate that the highest mean $\mathrm{L}_{\mathrm{eq}}$ was $71.0 \mathrm{dBA}$ on Saturday morning. On the other hand, the lowest mean $\mathrm{L}_{\mathrm{eq}}$ was $59.0 \mathrm{dBA}$ during the night shift on Monday. Therefore, in this environment, the $L_{e q}$ variability in the studied week was 12.0 dBA. Furthermore, the $L_{\text {eq } \max }$ was 95.1dBA on Saturday morning and the $L_{\text {eq min }}$ was $53.2 \mathrm{dBA}$ on Monday night.

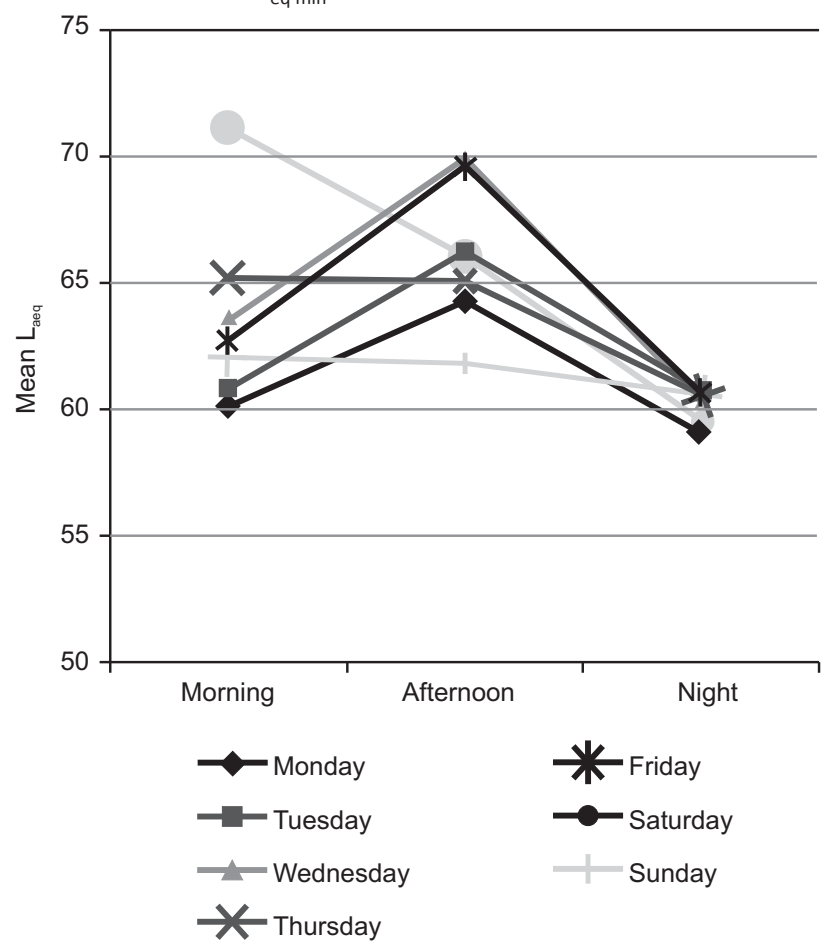

Figure 1 - Mean Leq (dBA) of NICU room A, by shifts and days of the week - São Paulo, SP, Brazil - 2009
Sound pressure levels in the Neonatal Intensive Care Unit Peixoto PV, Araújo MAN, Kakehashi TY, Pinheiro EM 
In NICU room $B$, the highest mean $L_{e q}$ was $68.0 \mathrm{dBA}$, recorded on Monday afternoon, and the lowest was 58.2 dBA on Saturday morning, with a variability of $9.8 \mathrm{dBA}$. It was found that the highest $\mathrm{L}_{\text {eq } \max }$ of this environment was 89.6 dBA on Monday night and the lowest $L_{\text {eq min }}$ was 44.4 dBA on Tuesday night.

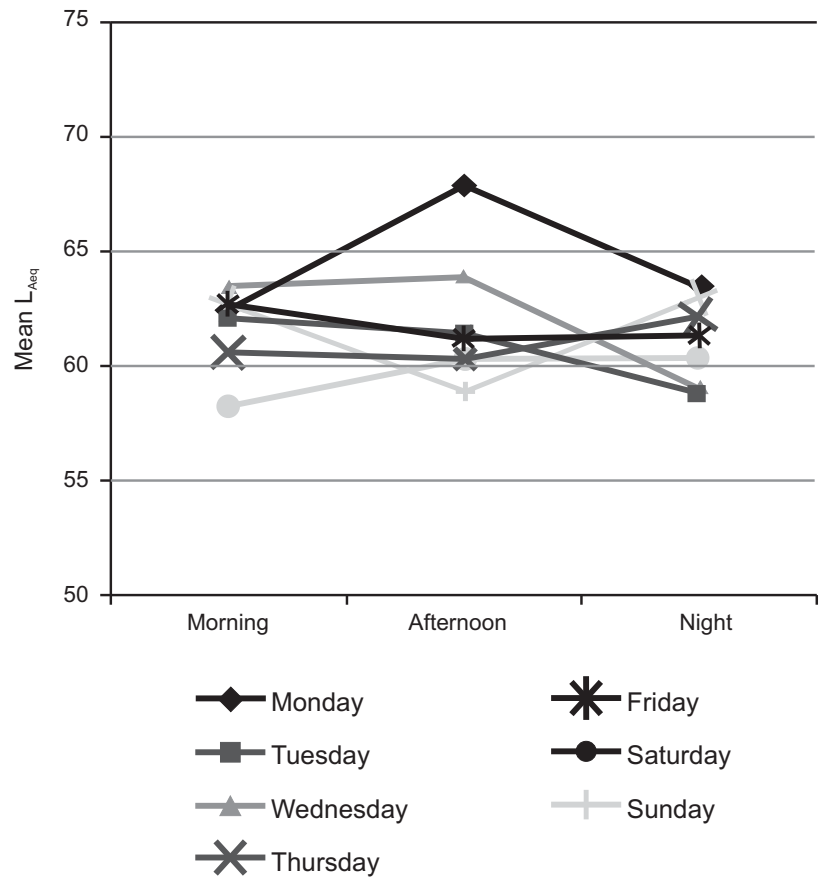

Figure 2 - Mean Leq (dBA) of NICU room B, by shifts and days of the week - São Paulo, SP, Brazil - 2009

By analyzing Figures 1 and 2, it is observed that the night shift was, relatively, more silent in room $A$, which is not observed in room $B$, in which the mean $L_{e q}$ of the three periods did not have such an expressive variation.

Considering the records from both rooms, the gross data show that there were rare occasions in which the neonates were exposed to SPL indicated by specialized agencies, as the $L_{\text {eq }}$ ranged between $54.0 \mathrm{~dB}(\mathrm{~A})$ and $95.1 \mathrm{~dB}(\mathrm{~A})$.

The main sound sources detected in both NICU rooms were: sound from the hallway $(14.5 \%$ of the recordings in room $A$ and $14.7 \%$ in room B), talk between workers ( $9 \%$ in room $A$ and $7.4 \%$ in room $B$ ), alarm sounds from life support devices (6.3\% in room $A$ and $11.8 \%$ in room $B$ ), sound caused by the oxygen/compressed air flow $(5.9 \%$ in room $A$ and $6.6 \%$ in room $B$ ) and the sound produced by shoe heels (6.5\% in room $A$ and $3.7 \%$ in room $B$ ). The sound caused by the traffic on the streets near the hospital was also an important factor, raising the SPL of the environments, corresponding to $14.5 \%$ of the recordings in room $A$ and $12.7 \%$ in room $B$.

\section{DISCUSSION}

The data from both rooms show SPL values above those recommended by regulatory agencies such as the Brazilian Technical Standards Association (Associação
Brasileira de Normas Técnicas - ABNT), which recommends values between 35 and $45 \mathrm{dBA}$ for hospital environments $^{(18)}$; the American Academy of Pediatrics (AAP), which recommends to avoid SPL above $45 \mathrm{dBA}^{(19)}$, and the World Health Organization ${ }^{(20)}$, which proposes the same $45 \mathrm{dBA}$. It should be stated that the studied NICU presented, most of the time, SPLs that rate it as noisy, because hospitals are considered quiet when the SPL is between 40 and $50 \mathrm{~dB}$; intermediate between 50 and $60 \mathrm{~dB}$, and noisy between $60-70 \mathrm{~dB}^{(21)}$.

However, the present results are in agreement with other NICU studies. A study performed at a teaching hospital in Ribeirão Preto-SP, Brazil, found smallest Leq of $49.9 \mathrm{dBA}$ and the highest of $88.3 \mathrm{dBA}^{(12)}$. At another teaching hospital in São Paulo -SP, the SPL ranged between 61.3 and $66.6 \mathrm{dBA}$, with the highest records on weekends ${ }^{(22)}$.

The present study hypothesis of high SPL noise sources can be explained by the excessive flow of workers. The NICU receives, in addition to the many workers, faculty and students of undergraduate and graduate courses of many health areas. Furthermore, the diversity, quantity, and the occasional rarity of the problems affecting the newborns at the studied NICU imply discussions about the conducts to be followed, and those discussions usually take place inside the room or in the hallway, with the room doors open. NICU teams take longer to change shifts and it usually takes place next to the beds, and procedures are performed at a slower pace (aiming at teaching purposes).

On the other hand, in the present study, taking into consideration the gross data, only the hallway noise reached a Leq of $65.5 \mathrm{~dB}$, recorded during the night shift. It should be stressed that the hallway is also a place where students usually stay. This conclusion was possible because at night there are fewer workers in the rooms and fewer procedures are performed.

The noise produced when nurses change shifts, along with the noise caused by the outside traffic and in the hallway, reached 59.2 dBA at night. Outside traffic produced about $56.4 \mathrm{dBA}$, while the noise generated by dragging the infusion pump reached SPL of up to $56.4 \mathrm{dBA}$. Sound levels above $70 \mathrm{dBA}$ were obtained in the early hours by the noise inside the building alone.

A North-American study performed using a dosimeter positioned in the center of a neonatal ward recorded the SPL generated while certain nursing procedures were performed; for instance, leaving the orogastric tube open resulted in levels of more than $75.3 \mathrm{~dB}$. Among the sources of noise found in this study and their respective sound pressure levels, the following were detected: placing the enteral diet container on the patients' bedside table, dragging the chair over the floor, letting the tap water run, alarm from the infusion pump and heart monitor, noise from the oxygen disconnected from the system, phone ringing at the nursing station, among others ${ }^{(10)}$. 
A NICU study performed by the Ribeirão Preto College of Nursing found that the lowest and highest Leq recorded were: 44.9 and $88.3 \mathrm{~dB}(\mathrm{~A})$, respectively. In that same study, peaks of 95.1 to $100.0 \mathrm{~dB}(\mathrm{C})$ represented $80.92 \%$ of the obtained integrated sound pressure levels ${ }^{(16)}$.

In this study, considering the data collection method used, it is concluded that the variables that resulted in the final SPL value are not occasional. These results reveal the everyday profile of the acoustic ecology of the NICU, considering that the sample covered the three work shifts on every day of the week for 14 days. The above data also indicate that a considerable part of the noise is triggered by care activities indispensible to the neonatal service and to their families, which makes it more difficult to perform environmental management that would result in a reduction of the SPL without building the awareness of the team and having them engage in the process.

Ecological issues in the hospital environment have, for some time, been the center of attention of nurses, though

\section{REFERENCES}

1. Schafer RM. A afinação do mundo: uma explanação pioneira pela história passada e pelo atual estado do mais negligenciado aspecto do nosso ambiente: a paisagem sonora. São Paulo: Ed. UNESP; 2001.

2. Standley JM. A meta-analysis of the efficacy of music therapy for premature infant. J Pediatr Nurs. 2002;17(2):107-13.

3. Bremmer P, Byers JF, Kiehl E. Noise and the premature infant: physiological effects and practice implications. J Obstet Gynecol Nenonatal Nurs. 2003;32(4):447-53.

4. Krueger C, Wall S, Parker L, Nealis R. Elevated sound levels within a busy NICU. Neonatal Netw. 2005;24(6):33-7.

5. Tomei F, Tomao E, Baccolo TP, Papaleo B, Alfi P. Vascular effects of noise. Angiology.1992;43(11):904-12.

6. Carvalho M, Vieira AA. Erro médico em pacientes hospitalizados. J Pediatr (Rio J). 2002;78(4):261-8.

7. Pinheiro EM, Silva MJP, Ângelo M, Ribeiro CA. The meaning of interaction between nursing professionals and newborns/families in a hospital setting. Rev Latino Am Enferm. 2008;16(6):1012-8.

8. Farella C. Quiet riot: newborn ICUS pump up the care and turndown the volume. Nurs Spectr. 2002;15(15):24-5.

9. Perlman JM. The genesis of cognitive and behavioral deficits in premature graduates of intensive care. Minerva Pediatr. 2003;55(2):89-101. literature stresses that there is need for nurses to implement interventions ${ }^{(23)}$.

\section{CONCLUSION}

This study revealed the high levels of sound pollution to which newborns and health professionals are exposed at the NICU. On the other hand, it was concluded that a project to reduce sound pollution levels at the NICU should address architectonic aspects, a program for preventive maintenance of equipment, and awareness among workers.

Therefore, after analyzing the results, a guideline was designed, which contemplated all the aforementioned aspects. An educational program was also implemented with a view to reduce the noise at the neonatal unit for further measurements.

10. DePaul D, Chambers SE. Environmental noise in the neonatal intensive care unit: implications for nursing practice. J Perinat Neonatal Nurs. 1995;8(4):71-6.

11. Rodarte MDO, Scochi CGS, Leite AM, Fujinaga Cl, Zamberlan NE, Castral TC. O ruído gerado durante a manipulação das incubadoras: implicações para o cuidado de enfermagem. Rev Latino Am Enferm. 2005;13(1):79-85.

12. Ichisato SMT, Scochi CGS. Ruídos na unidade de cuidado intensivo neonatal durante as passagens de plantão (enfermagem e/ou médica) e visita médica. Ciênc Cuidado Saúde. 2006;5 Supl:127-33.

13. Robertson A, Kohn J, Vos P, Cooperpeel C. Establishing a noise measurement protocol for neonatal intensive care units. J Perinatol. 1998;18(2):126-30.

14. Pereira RP. Qualificação e quantificação da exposição sonora ambiental em uma Unidade de Terapia Intensiva geral. Rev Bras Otorrinol. 2003;69(6):766-71.

15. Associação Brasileira de Normas Técnicas (ABNT). NBR 10152 - Níveis de ruídos para conforto acústico. Rio de Janeiro: ABNT; 2000.

16. Ichisato SMT. Ruído em uma unidade de cuidado intermediário neonatal de um hospital universitário. Ciênc Cuidado Saúde. 2008;7(4):431-8.

17. Zahr LK, Balian S. Responses of premature infants to routine nursing interventions and noise in the NICU. Nurs Res. 1995;44(3):179-85.
Sound pressure levels in the Neonatal Intensive Care Unit Peixoto PV, Araújo MAN, Kakehashi TY, Pinheiro EM 
18. Associação Brasileira de Normas Técnicas (ABNT). NBR 10151 - Acústica: avaliação do ruído em áreas habitadas visando o conforto da comunidade - procedimento. Rio de Janeiro: ABNT; 2000.

19. American Academy of Pediatrics; Committee on Environmental Health. Noise: a hazard for the fetus and newborn. Pediatrics. 1997;100(4):724-7.

20. World Health Organization (WHO). Guidelines values [Internet]. London; 1999 [cited 2004 Nov 2]. Available from: http://www.who.int/docstore/peh/noise/Commnoise4.htm
21. Minckley BB. A study of noise and its relationship to patient discomfort in the recovery room. Nurs Res. 1968;17(3):247-50.

22. Kakehashi TY, Pinheiro EM, Pizzarro G, Guilherme A. Nível de ruído em uma UTI Neonatal. Acta Paul Enferm. 2007;20(4):404-9.

23. Ribeiro MCS, Bertolozzi MR. Reflexões sobre a participação de enfermeiras nas questões ecológicas. Rev Esc Enferm USP. 2002;36(4):300-8.

\section{Acknowledgements}

The authors thank the nursing team of the Neonatal Intensive Care Unit where the data were collected. This study was performed with the support from the State of São Paulo Research Foundation (FAPESP) Processo no: 2008/50874-9 